\title{
UPAYA MENINGKATKAN HASIL BELAJAR BAHASA INDONESIA \\ DENGAN MODEL MODELING THE WAY BERBANTUAN MEDIA AUDIO VISUAL PADA SDN 5 TELANGKAH TAHUN PELAJARAN 2016/2017
}

\author{
Oleh \\ Prestini $^{1}$, Diplan ${ }^{2}$ \\ Email: diplan161181@gmail.com
}

\begin{abstract}
This study aims to improve learning outcomes and describe the activities of students in learning Indonesian with the Modeling Model of The Way Unified Audio Visual Media. The method used in this study is class action. The subjects in this study were all $\mathrm{Vb}$ grade students of SDN 5 Telangkah which numbered 35. The results of the study showed that the activities of students became good and learning outcomes increased. This can be seen from the increase in activity, enthusiasm, and enthusiasm of students in participating in the learning process with an average value of 3.37 in the good category. The increase in Indonesian language learning outcomes seen from the initial test averages 61 with classical completeness $37.14 \%$ and experienced an increase in the first cycle with the acquisition of indigo scores of 87 students with $91.42 \%$ classical completeness in Indonesian subjects especially in drama discipline material.
\end{abstract}

(C) Muhammadiyah University Palangkaraya

Keywords: Indonesian language learning outcomes, modeling the way, audio visual media

\begin{abstract}
ABSTRAK
Penelitian ini bertujuan untuk peningkatan hasil belajar dan mendeskripsikan aktivitas peserta didik pada pembelajaran Bahasa Indonesia dengan model Modeling The Way Berbatuan Media Audio Visual. Metode yang digunakan dalam penelitian ini adalah tindakan kelas. Subjek dalam penelitia ini adalah seluruh peserta didik kelas Vb SDN 5 Telangkah yang berjumlah 35. Hasil penelitian menunjukan bahwa Aktifitas peserta didik menjadi baik dan hasil belajar meningkat. Hal tersebut dapat dilihat dari adanya peningkatan aktivitas, antusias, dan semangat peserta didik pada mengikuti proses pembelajaran dengan nilai rata- rata 3,37 dengan kategori baik. Peningkatan hasil belajar Bahasa Indonesia dilihat dari tes awal rata- rata 61 dengan ketuntasan klasikal $37,14 \%$ dan mengalami peningkatan pada pada siklus I dengan perolehan nila rata- rata peserta didik 87 dengan ketuntasan klasikal 91,42 \% pada mata pelajaran Bahasa Indonesia khususnya pada materi drama kedisiplinan.
\end{abstract}

(C) Universitas Muhammadiyah Palangkaraya

Kata Kunci: hasil belajar bahasa indonesia, modeling the way, media audio visual. 


\section{PENDAHULUAN}

Dalam undang- undang No.20 Tahun 2003, tentang sistem pendidikan Nasional, menyatakan bahwa pendidikan diartikan sebagai usaha sadar dan terencana untk mewujutkan suasana belajar dan peroses pembelajaran agar peserta didik secara aktif mengembangkan potensi dirinya untuk memiliki kekuatan spiritual keagamaan, pengendalian diri, keperibadian, kecerdasan akhlak mulia, serta keterampilan yang diperlukan dirinya, masyarakat bagsa dan negara.

Tujuan pendidikan Nasional adalah mengembangkan potensi peserta didik agar menjadi manusia yang beriman dan bertaqwa kepada Tuhan Yang Maha Esa, berakhlak mulia, sehat, berilmu, cakap, kereatif, mandiri, dan menjadi warga yang demoskratis, serta bartanggung jawab dalam mencerdaskan kehidupan bangsa.

Pembelajaran adalah suatu upaya atau kegiatan yang dilakukan oleh guru secara terprogram menggunakan berbagai strategi, metode, model, dan pendekatan dalam mencapai tujuan yang telah dirancang dengan sedemikian rupa untuk membuat peserta didik belajar secara aktif. Sehingga proses interaksi antara guru dengan peserta didik, baik secara langsung seperti

kegiatan tatap muka maupun secara tidak langsung, yaitu dengan menggunakan berbagai media pembelajaran.

Menurut Dra. Arnie Fajar (2009: 15-16) Kegiatan pembelajaan dilaksanakan dengan menerapkan strategi dan metode pembelajaran yang menyenakan, kontestual, efektif, efesien, dan bermakna. Sehingga kegiatan pembelajaran mampu meningkatkan kompetensi, kereativitas, kemandirian, kerjasama, solidaritas, kepemimpinan, empati, toleransi, dan kecakapan hidup peserta didik guna membentuk watak serta meningkatkan peradapan dan martabat bangsa.

Bahasa Indonesia merupakan salah satu mata pelajaran yang ada di SD dimana mata pelajaran ini memiliki peran yang sangat penting dalam memberikan pengetahuan, gagasan dan konsep yang terorganisasi dengan baik tentang tata bunyi yang dihasilkan oleh alat ucap manusia, tata bentuk kata, tata kalimat, bahas tulisan berbentuk huruf dan tanda baca dari bahasa lisan. Pengajaran Bahasa Indonesia berkaitan dengan penguasaan terhadap bahasa lisan dan tulisan sehingga proses komunikasi dapat tercapai.

Berdasarkan dari hasil pengamatan peneliti melalui observasi dan wawacara dengan guru kelas $\mathrm{Vb}$ SDN 5 Telangkah pada mata pelajaran Bahasa Indonesia bahwa hasil belajaran Bahasa Indonesia masih rendah dan dibawah KKM (70). Karena saat proses pembelajaran berlansung perserta didik kurang partisipasi dan nampak pasif sehingga proses pembelajaran masih berpusat kepada guru dimana guru masih medominasi proses pembelajaran.

Karena keterbatasan waktu guru mengajar membuat guru menjadi malas menggunakan berbagai model- model pembelajaran yang bermacam- macam dan banyak memakan waktu sehingga guru lebih suka menggunakan model pembelajaran ceramah, karena guru 
beranggapan model ceramah adalah model yang sangat mudah diterapkan di kelas dan tidak terlalu banyak memakan waktu.

Berdasarkan latar belakang di atas maka peneliti berupaya membantu untuk meningkatkan hasil belajar Bahasa Indonesia dengan menerapkan strategi model modeling the way berbantuan audio visual dimana kegiatan pembelajaran lebih memberikan kesempatan kepada peserta didik untuk menciptakan skenario atau langkah- langkah kerja sendiri dan menentukan bagaimana melilustrasikan atau memperaktekan keterampilan dan teknik yang baru saja dijelaskan dengan waktu yang terbatas lalu di demostrasikan didepan kelas. Sedangkan fungsi strategi modeling the way termasuk model pembelajaran aktif dan mampu memaksimalkan potensi yang dimiliki oleh peserta didik dalam proses pembelajaran.

\section{METODE PENELITIAN}

Penelitian ini menggunakan Penelitian Tindakan Kelas (PTK). Penelitian Tindakan Kelas (PTK) adalah penelitian tindakan yang dilakukan dengan tujuan memperbaiki mutu praktik pembelajaran di dalam kelas.

Menurut Abdulhak Ishak dkk (2012: 93) peneliti tindakan adalah penelitian reflektif yang dilaksanakan secara siklus (berdaur) oleh pengelola pendidikan, baik guru, tutori, programer, maupun perancang program lainnya. Dikatakan demikian karena proses penelitian tindakan dimulai dari tahap perancanan, tindakan, pengamatan, dan refleksi untuk memecahkan masalah dan mencoba halhal baru demi menikatkan kualitas pembelajaran.

Kunandar (2012:45) "penelitian tindakan kelas ada tiga unsur atau konsep, yakni sebagai berikut".

1. Penelitian adalah aktivitas mencermat suatu objek tertentu melalui metodologi ilmiah dengan mengumpulkan data-data dan dianalisis untuk menyelesaikan suatu masalah.

2. Tindakan adalah suatu aktivitas yang sengaja dilakukan dengan tujuan tertentu yang berbentuk siklus kegiatan dengan tujuan memperbaiki atau meningkatkan mutu atau kualitas proses belajar mengajar.

3. Kelas adalah sekelompok siswa dalam waktu yang sama menerima pelajaran yang sama dari seorang guru.

Dalam mengambil data penelitian mengunakan dua buah alat bantu yaitu lembar observasi dan tes. Observasi digunakan untuk mengamati proses pembelajaran menggunakan model modeling the way berbantuan audio visual dan tes dilakukan untuk mengukur tingkat keberhasilan setiap siklus nya.

Menurut Sugiyono (2016:203) "Teknik pengumpulan data dengan observasi digunakan bila, penelitian berkanaan dengan perilaku manusia, proses kerja, gejala- gejala alam dan bila respondenyang diamati tidak terlalu basar".

Menurut Sugiyono (2016:148) "Instrumen penelitian adalah suatu alat yang digunakan megukur fenomena 
alam maupun sosial yang diamati. Sedangkan menurut

Arikunto Suharsimi (2006:160) instrumen pengumpulan data adalah alat bantu yang dipilih dan digunakan peneliti didalam kegiatan pengumpulan data agar kegiatan lebih mudah dan hasil lebih baik, dalam artian lebih cermat, lengkap dan sistematis.

\section{HASIL DAN PEMBAHASAN}

Aktivitas belajar Bahasa Indonesia peserta didik kelas Vb SDN 5 Telangkah dengan menggunakan model Modeling The Way Berbantuan media Audio Visual menjadi baik.

Berdasarkan analisis data pada bulan April sampai Juni 2017 bahwa hasil aktivitas peserta didik pada saat pembelajaran berlangsung masih kurang karena peserta didik kurang memehami materi pembelajaran Bahasa Indonesia yang disampaikan oleh guru sehingga berpengaruh pada hasil belajar peserta didik yang rendah. Oleh karna itu peneliti menerapkan judul "Upaya Meningkatkan Hasil Belajar Bahasa Indonesia Dengan Model Modeling The WayBerbantuan Media Audio Visual Pada Peserta Didik Kelas Vb SDN 5 Telangkah agar hasil belajar peserta didik lebih baik. Oleh karena penelitian dilakukan kedalam 1 siklus dan setiap siklusnya terdiri dari 4 tahap yaitu 1) perencanaan tindakan siklus, 2) pelaksanaan tindakan kelas, 3) observasi siklus, 4) refleksi siklus. Sebelum melakukan siklus 1 peneliti terlebih dulu melakukan tes awal (pra tindakan) kepada peserta didik agar peneliti mengetahui seberapa jauh aktifitas belajar dan hasil belajar peserta didik sebelum peneliti menerapkan model modeling the way. Data hasil tes awal (pra tindakan) peserta didik berjumlah 2150, data rata- rata keseluruhan peserta didik 61 dan nilai ketuntasan klasikal peserta didik $37,14 \%$

Dengan data dari tes awal inilah peneliti merasa perlu melakukan tindakan kelas siklus I yang dilakukan pada hari selasa,09 mei 2017. Penelitian pada siklus I peneliti menerapkan model modeling the way berbantuan media audio visual dengan dibantu oleh 2 observer (pengamat) yaitu pengamat 1 guru kelas $\mathrm{Vb}$, dan pengamat 2 adalah teman sejawat. Berdasarkan lembaran observer aktivitas peserta didik maka diperoleh data siklus I yaitu dari 35 orang peserta didik skor rata adalah 3,37 dengan kriteria baik sehingga hal ini menunjukkan bahwa peserta didik lebih aktif saat proses pembelajaran Bahasa Indonesia berlangsung dengan menggunakan model modeling the way berbantuan media audio visual.

Berdasarkan analisis data yang dilakukan terhadap peserta didik maka dapat disimpulkan dari hasil tes awal terhadap 35 peserta didik ada 22 peserta didik yang tidak tuntas sehingga peneliti perlu melakukan tindakan kelas terhadap kelas $\mathrm{Vb}$ SDN 5 Telangkah dengan menerapkan model modeling the way berbantuan media audio visual.

Data hasil pada siklus I adalah hari selasa tanggal 09 mei 2017 menunjukan bahwa hasil belajar peserta didik mengalami peningkatan dengan menggunakan model modeling the way berbantuan media audio visual, jumlah skor nilai dari peserta didik adalah 3060 
dengan rata- rata 87 dan ketuntasan klasikal 91,42 \%. Dan pada siklus ini ada 3 peserta didik yang belum tuntas, maka dari itu pembelajaran Bahasa Indonesia secara keseluruhan sudah mencapai ketuntasan klasikal. Hipotesis penelitian yang menyatakan bahwa aktivitas belajar peserta didik pada saat proses pembelajaran IPA dengan menerapkan model pembelajaran kooperatif tipe Time Game Tournament menggunakan media benda konkrit menjadi baik. Hal ini terbukti dari keaktifan belajar peserta didik pada saat proses pembelajaran berlangsung dan dibuktikan dari hasil pengamatan yang terdiri dari dua orang pengamat, pengamat pertama yaitu guru kelas IV SDN-4 Kasongan Lama dan pengamat ke 2 adalah teman sejawat skor yang diperoleh adalah 3,7 yang termasuk ke dalam kategori baik.

Dalam penelitian ini hasil belajar IPA peserta didik setelah menerapkan model pembelajaran Time Game Tournament menggunakan media benda konkrit mengalami peningkatan. Hal ini dibuktikan dari hasil rata-rata belajar pre-test yaitu 58. Dan pada hasil ketuntasan belajar secara klasikal pretest yaitu $41 \%$ atau hanya ada 14 orang peserta didik yang tuntas belajar, pada post-test siklus I meningkat menjadi $100 \%$ atau semua orang peserta didik tuntas belajar.

\section{KESIMPULAN}

Aktifitas peserta didik kelas $\mathrm{Vb}$ SDN 5 Telangkah dengan menggunakan
Model Modeling The Way berbantuan media audio visual pada belajar Bahasa Indonesia meningkat menjadi baik. Hal tersebut dapat dilihat dari adanya peningkatan aktivitas, antusias, dan semangat peserta didik pada mengikuti proses pembelajaran dengan nilai ratarata 3,37 dengan kategori baik.

Ada peningkatan hasil belajar Bahasa Indonesia dengan menggunakan Model Modeling The Way berbantuan media audio visual pada peserta didik kelas $\mathrm{Vb}$ SDN 5 Telangkah. Peningkatan tersebut dapat dilihat dari tes awal rata- rata 61 dengan ketuntasan klasikal $37,14 \%$ dan mengalami peningkatan pada pada siklus I dengan perolehan nila rata- rata peserta didik 87 dengan ketuntasan klasikal 91,42 \% pada mata pelajaran Bahasa Indonesia khususnya pada materi drama kedisiplinan.

\section{DAFTAR PUSTAKA}

Abdulhak Ishak, Ugi Suprayogi. (2012). Penelitian Tindakan Dalam Pendidikan Nonformal. Jakarta: PT Rajagrafindo Persada

Arikunto, Suharsimi. (2006). Analisis Butir Tes. Surabaya: Universitas Press

Fajar, Arnie. (2009). Portofolio Dalam Pembelajaran IPS. Bandung: PT Remaja Rosdakarya

Kunandar. (2012). Penelitian Tindakan Kelas. Jakarta: Raja Grafindo Persada

Sugiyono (2016). Metode Penelitian Pendidikan kuantitatif, kualitatif, dan $R \& B$. Bandung: Alfabeta, CV. 